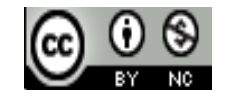

Jurnal Pendidikan Matematika Indonesia is licensed under

A Creative Commons Attribution-Non Commercial 4.0 International License

\title{
EFFORTS TO IMPROVE STUDENT'S SELF CONFIDENCE USING Collaborative Learning MODEL
}

\author{
Nurhayati $^{1)}$, Rosmaiyadi ${ }^{2)}$, Buyung ${ }^{3)}$ \\ 1) Prodi Pendidikan Matematika STKIP Singkawang, Kalbar, Indonesia \\ E-mail: nurhayati@stkipsingkawang.ac.id \\ 2) Prodi Pendidikan Matematika STKIP Singkawang, Kalbar, Indonesia \\ E-mail: rosmaiyadialong@gmail.com \\ 3) Prodi Pendidikan Matematika STKIP Singkawang, Kalbar, Indonesia \\ E-mail:21.buyung@gmail.com
}

\begin{abstract}
One way to improve students' self-confidence is to implement a collaborative learning model. Improving students' selfconfidence using collaborative learning models can be done by conducting classroom action research. The subject of this class action research is the students of class X MIPA 4 SMA Negeri 2 Ngaglik, Sleman, Yogyakarta School Year 2015/2016 consisting of thirty two students. This study consists of two cycles. Technique Data collection used is test and non test. The instrument of this study is the test of student achievement and student confidence questionnaire. Data analysis techniques consisted of the conversion of qualitative data to quantitative and student mastery calculation. The average of student achievement before treatment is 40.3125 with the complete proportion of students is $3.125 \%$ and after treatment is 87.9167 with proportion of student which is complete is $100 \%$. The average student self-confidence before treatment was 96.46875 with moderate category and after treatment was 109.2188 with high category. The results showed that collaborative learning model can improve student's self-confidence.
\end{abstract}

Keywords: Collaborative, Self Confidence

\section{INTRODUCTION}

One of the fundamental problems in mathematics education in Indonesia is the low achievement of students and the lack of developing the affective and psychomotor aspects of students on learning mathematics in schools. In teaching mathematics, classroom learning is almost always carried out conventionally in the order of presentation: (1) taught theories/definitions/theorems through notices, (2) given and discussed examples, then (3) given practice questions. As a result, until now the quality of mathematics learning in Indonesia is still low (Zuliana, 2008).

Each institution always has a goal to be achieved. Similarly with education in Indonesia, there are various goals and competencies to be achieved in education in Indonesia. The various objectives and competencies are set out in government regulations and so forth. One of the objectives or competences to be achieved in education in Indonesia as stated in Permendikbud Number 64 of 2013 on Basic and Secondary Education Content Standards is that students have curiosity, confidence, and interest in mathematics.

Goel \& Aggarwal (2012) mentions that confident people feel socially competent, mature emotionally, sufficient in intelligence, success, satisfaction, firm, optimistic, independent, confident, confident, constantly moving, and have leadership qualities. It can be said that the existence of self-confidence is very important in students because it will allow students to be able to believe in the ability possessed, not easily give up in the face of every problem so that students are able to perform all tasks provided independently and with maximum results. It is therefore important to instill self-confidence in students. According to Srivastava (2013) 
Confidence is one of the attitudes possessed by each individual who has a positive outlook on himself and his situation. Confidence is the belief in self and self-ability, a mental attitude that trusts or relies on oneself.

But in fact, the conditions that occur in the field is not in accordance with the desired conditions. Based on the results of interviews with one of the teachers in SMA Negeri 2 Ngaglik Yogyakarta conducted on September $25^{\text {th }}, 2015$ obtained the results that some students' self confidence is good, but there are still students who have less confidence.Therefore, efforts should be made to improve student confidence. One of the solutions offered by researchers is using a collaborative learning model.

According to (Laal \& Laal, 2011), collaborative learning is a learning that involves grouping students to work together in solving a problem, task, or product creation. Students in the group decide and find out for themselves how they are solving a problem, task, or product without direct direction from the teacher. Therefore, the freedom given in collaborative learning really emphasizes students to actively participate in joint tasks. This will certainly make students better understand the concepts they are learning and can develop student self-confidence.

In addition, Adams \& Hamm (2010) has an opinion that: Collaborative learning of this type is effective because the framework of the strategy is good for all students. The research also suggests that some-what collaborative learning groups result in more cross-cultural friendships and have some positive effect in intergroup relations. With an increasingly diverse group of students, learning to advance through the intersection of different points of views is more important than ever.

Goodsell, Maher, Tinto, et al (1992) stated that ideally, collaborative learning makes students more focused on expressing ideas in the classroom. They build their confidence and expertise in expressing ideas they have in learning when answering questions, listening carefully and responding to questions from other friends. They build their ability to stay focused, maintain an idea, build relationships with some students and learn how to politely reject or accept other students' opinions.

Wagman (1997) adding exercises that can be used to improve self-confidence are as follows:"Emphasize yourself, avoid doing too much too soon, be flexible, be realistic, goals outside of sport, keep a log, focus on the process rather than the outcome, consider many factors, and prioritize. Parachin (2003) state that "Here are seven key steps for developing dynamic selfconfidence: 1) Begin with the 'As-If Principle', 2) Accept responsibility, 3) Don't let what you speak make you weak, 4) Take the dare, 5) Reject negative advice, 6) Follow the positive voices, and 7) Make anxiety your ally.

Based on the description that has been put forward, it can be concluded that there are problems that occur in the field. One of the competencies that should be achieved by the students as stated in Permendikbud Number 65 of 2013 on Basic and Secondary Education Content Standards is that students have curiosity, confidence, and interest in mathematics. However, based on the results of interviews conducted revealed that students' self-confidence is still escape from the focus of teachers. Therefore, the researcher is interested to conduct research on "Efforts to Improve Self Confidence of Student of Class X MIPA 4 Using Collaborative Learning Model".

The formulation of problems that can be described based on the background, problem identification, and problem restrictions are (1) How to improve the confidence of students of class X MIPA 4 SMA Negeri 2 Ngaglik Yogyakarta in learning mathematics through collaborative learning model? And (2) How is the implementation of mathematics lesson class $\mathrm{X}$ MIPA 4 SMA Negeri 2 Ngaglik Yogyakarta through collaborative learning model in improving students' mathematical self-confidence?

The purpose of this study is (1) Increasing confidence of students in grade X MIPA 4 SMA Negeri 2 Ngaglik Yogyakarta through collaborative learning model and (2) Describe the implementation of mathematics learning class $\mathrm{X}$ MIPA 4 SMA Negeri 2 Ngaglik Yogyakarta 


\section{A - - - Jurnal Pendidikan Matematika Indonesia \\ Volum 2 Nomor 2 bulan September 2017. Page 57-62 \\ p-ISSN: 2477-5967 e-ISSN: 2477-8443}

through collaborative learning model in increasing trust self-math students.

\section{METHODS}

Methods of this research are classroom action research and classroom action research cycle model used is based on model from Kemmis \& McTaggart (1988). According to Kemmis \& McTaggart (1988) in Burns (2010), classroom action research is a type of research consisting of 4 stages in a cycle. These stages are planning, action, observation, and reflection. The first cycle may continue into the next cycle until the action research gets the desired result (Srivastava, 2013). This research was conducted in SMA Negeri 2 Ngaglik, Sleman, Yogyakarta with the subject of research is the students of class X MIPA 4 SMA Negeri 2 Ngaglik, Sleman, Yogyakarta academic year 2015/2016 which amounted to thirty two students. The action taken in this research is applying collaborative learning model in grade $\mathrm{X}$ students MIPA 4 SMA Negeri 2, Ngaglik, Sleman, Yogyakarta to improve student's learning achievement and confidence. Technique of collecting data in this research is test and non test. The research instrument is a learning achievement test consisting of 15 questions and a selfconfidence questionnaire consisting of 29 points of statement. The success indicator of this classroom action research is the achievement of student activity and achievement through the application of collaborative learning model with the following conditions:

TABLE I

CRITERIA FOR ACTION SUCCESS

\begin{tabular}{llll}
\hline Variable & Interval & Criteria & Target \\
\hline & $116<\mathrm{X} \leq 145$ & Very High & $12,5 \%$ \\
& $96,67<\mathrm{X} \leq 116$ & High & $75 \%$ \\
Student's Self & $77,3<\mathrm{X} \leq 96,67$ & Medium & $12,5 \%$ \\
Confidence & $58<\mathrm{X} \leq 77,3$ & Low & $0 \%$ \\
& $29<\mathrm{X} \leq 58$ & Very Low & $0 \%$ \\
& $\begin{array}{l}\text { Average }= \\
96,46875\end{array}$ & Medium & 106 \\
& $\begin{array}{l}\text { Student complete } \\
\geq 75 \%\end{array}$ & KKM achieved \\
\hline \multirow{3}{*}{ Knowledge/Skill } & Avergae $=75$ & & $80 \%$ \\
& $\begin{array}{l}\text { Has been held } \geq \\
75 \%\end{array}$ & Learning & 80 \\
\hline Learning process & Successful & $80 \%$ \\
\hline
\end{tabular}

Research data analyzed were test and questionnaire data before and after treatment, which included pre-test and post-test data for student achievement and student self-confidence. Analysis of test and questionnaire data prior to treatment is intended to determine the initial description of the two classes. While the analysis of test data and questionnaires after the treatment is intended to know the final description of the two classes.

The confidence data described is the number of students' self-confidence questionnaires score in the mathematics learning process that students get to be categorized based on the standard score that has been converted. Then, to measure student's learning mastery used the following formula:

$$
\mathrm{KB}=\frac{P}{N} x 100 \%
$$

Keterangan:

KB : Learning complete

$\mathrm{P} \quad$ : Amount Student that get value 75 or High

$\mathrm{N} \quad$ : Amount all of student

Learning complete achieved if $\mathrm{KB} \geq 80 \%$ student get value 75 .

In addition, the data of student achievement is analyzed descriptively by determining the average score of test result with the formula:

$$
M=\frac{\sum_{i=1}^{n} x_{i}}{N}
$$

Keterangan :

$\mathrm{M}=$ student score average

$x_{i}=$ Ever student score

$\mathrm{N}$ = amount student that follow exam

III. RESULTS AND DISCUSSION

\section{RESULTS}

This classroom action research was conducted to improve the quality of mathematics learning in class $X$ MIPA 4 SMA Negeri 2 Ngaglik Yogyakarta. This research was conducted in two cycles, from October $30^{\text {th }}, 2015$ to November $21^{\text {st }}$, 2015. The object of this study is the students of class $\mathrm{X}$ MIPA 4 SMA Negeri 2 Ngaglik Yogyakarta academic year 2015/2016 as many as 32 people. In this study applied model of 
collaborative learning as an effort to improve students' self confidence in learning mathematics so that will have a direct impact on the improvement of learning achievement. Details of the research implementation and the results of each cycle are described below:

\section{A. Cycle 1}

Mathematical learning that applied the collaborative learning model in cycle I was held in 2 meetings (October $31^{\text {st }}$ and November $7^{\text {th }}, 2015$ ), where each meeting lasted for $2 \times 45$ minutes. The material discussed in cycle $\mathrm{I}$ is the concept of matrix, matrix types, transposes and matrix similarities.

\section{Implementation and observation stage}

At this stage the activities undertaken are to carry out all the items contained in the preparation stage. At the fourth meeting conducted an evaluation to determine student achievement in cycle I.

The learning achievement of cycle $\mathrm{I}$ is calculated from the value of cycle test conducted on November $8^{\text {th }}, 2015$ for 90 minutes. The statistical achievement of student learning, student confidence, and implementation of learning in cycle I are as follows:

TABLE II

Student LeARning ACHIEVEMENT Statistic, StUdENT's SeLF CONFIDENCE, AND LEARNING IMPLEMENTATION IN CYCLE 1

\begin{tabular}{|c|c|c|c|c|c|c|}
\hline Variable & Interval & Criteria & \multicolumn{2}{|c|}{ Initial Condition } & \multicolumn{2}{|c|}{ Final Cycle 1} \\
\hline \multirow{6}{*}{$\begin{array}{l}\text { Student's Self } \\
\text { Confidence }\end{array}$} & $116<\mathrm{X} \leq 145$ & Very High & \multicolumn{2}{|c|}{$0 \%$} & \multicolumn{2}{|c|}{$6,25 \%$} \\
\hline & $96,67<\mathrm{X} \leq 116$ & High & \multicolumn{2}{|c|}{$71,875 \%$} & \multicolumn{2}{|c|}{$78,125 \%$} \\
\hline & $77,3<\mathrm{X} \leq 96,67$ & Medium & \multirow{2}{*}{\multicolumn{2}{|c|}{$12,5 \%$}} & \multirow{2}{*}{\multicolumn{2}{|c|}{$9,375 \%$}} \\
\hline & $58<\mathrm{X} \leq 77,3$ & Low & & & & $6,25 \%$ \\
\hline & $29<\mathrm{X} \leq 58$ & Very Low & \multicolumn{2}{|c|}{$6,25 \%$} & \multicolumn{2}{|c|}{$0 \%$} \\
\hline & $\begin{array}{c}\text { Average }= \\
96,46875\end{array}$ & Medium & \multicolumn{2}{|c|}{$\begin{array}{l}96,46875 \\
\text { (Medium) } \\
\end{array}$} & \multicolumn{2}{|c|}{$\begin{array}{c}103,1563 \\
\text { (High) }\end{array}$} \\
\hline \multirow{2}{*}{ Knowledge/Skill } & $\begin{array}{c}\text { Student Complete } \geq \\
75 \%\end{array}$ & \multirow{2}{*}{$\begin{array}{c}\text { KKM } \\
\text { achieved }\end{array}$} & \multicolumn{2}{|c|}{$3,125 \%$} & \multicolumn{2}{|c|}{$59,375 \%$} \\
\hline & Average $=75$ & & \multicolumn{2}{|c|}{40,3125} & \multicolumn{2}{|c|}{77,1875} \\
\hline \multirow{3}{*}{ Learning Process } & & & Teacher & Student & Teacher & Student \\
\hline & $\begin{array}{c}\text { Has been held } \geq 75 \\
\%\end{array}$ & $\begin{array}{c}\text { Learning } \\
\text { successful } \\
>80 \%\end{array}$ & $<50 \%$ & $<50 \%$ & $92,61 \%$ & $91,67 \%$ \\
\hline & & & \multicolumn{2}{|c|}{$<50 \%$} & \multicolumn{2}{|c|}{$93 \%$} \\
\hline
\end{tabular}

These results indicate that the average student achievement is 77.1875 and the percentage of completed students is $59.375 \%$. This shows that the completeness of learning achievement in the first cycle has not been achieved even though the trust is in the high category, but the average class has not reached the desired target of 106 with the high category.

\section{B. Cycle 2}

Mathematics learning that applied collaborative learning model in cycle I was held in 2 meetings (November $14^{\text {th }}$ and $20^{\text {th }}, 2015$ ), where each meeting lasted for $2 \times 45$ minutes. The material discussed in cycle II is simple matrix operations. The learning achievement of cycle II is calculated from the value of cycle test conducted on November $21^{\text {st }}$, 2015 for 90 minutes. The statistical achievement of student learning, student confidence and implementation of learning in cycle II are as follows:

TABLE III

STUdENT LEARNING ACHIEVEMENT STATISTIC, STUDENT's SELF CONFIDENCE, AND LEARNING IMPLEMENTATION IN CYCLE 1I

\begin{tabular}{|c|c|c|c|c|}
\hline Variable & Interval & Criteria & Initial Condition & Final Cycle II \\
\hline \multirow{6}{*}{$\begin{array}{l}\text { Student's Self } \\
\text { Confidence }\end{array}$} & $116<\mathrm{X} \leq 145$ & Very High & $6,25 \%$ & $12,5 \%$ \\
\hline & $96,67<X_{\leq} \leq 116$ & High & $78,125 \%$ & $78,125 \%$ \\
\hline & $77,3<X \leq 96,67$ & Medium & $9,375 \%$ & $9,375 \%$ \\
\hline & $58<\mathrm{X} \leq 77,3$ & Low & $6,25 \%$ & $0 \%$ \\
\hline & $29<\mathrm{X} \leq 58$ & Very Low & $0 \%$ & $0 \%$ \\
\hline & Average $=96,46875$ & Medium & 103,1583 (High) & 109,2188 (High) \\
\hline \multirow{2}{*}{ Knowledge/Skills } & $\begin{array}{c}\text { Student complete } \geq \\
75 \%\end{array}$ & \multirow{2}{*}{ KKM achieved } & $12,5 \%$ & $100 \%$ \\
\hline & Average $=75$ & & 57,5 & 87,9167 \\
\hline \multirow{3}{*}{ Learning Process } & \multirow{3}{*}{$\begin{array}{c}\text { Has been held } \geq 75 \\
\%\end{array}$} & \multirow{3}{*}{$\begin{array}{l}\text { Learning } \\
\text { successful } \\
\geq 80 \%\end{array}$} & Teacher & Teacher Student \\
\hline & & & $92,61 \% \quad \begin{array}{c}91,67 \\
\%\end{array}$ & $100 \%$ \\
\hline & & & $93 \%$ & $100 \%$ \\
\hline
\end{tabular}

These results indicate that there is an increase in student achievement when compared with cycle I. Student confidence in cycle II also increased and can be categorized in high category. Student achievement and self-confidence have reached the target in cycle II.

\section{DISCUSSION}

This classroom action research applies a collaborative learning model. Learning begins with the stages of formulate, share, listen, and create that applied in research in class X MIPA 4 SMA Negeri 2 Ngaglik Yogyakarta. Mathematical learning with collaborative learning model begins by giving motivation and apperception. It is intended to prepare students in learning and refreshment of the material they have and which will be used in learning. Learning is also 
associated with the real world, namely by presenting a contextual problem. Contextual issues are provided through the Student Worksheet (LKS). In group discussions, students work on contextual issues with little or no teacher help, so students can build on their own learning experiences. The given problem refers to the student manual, making it easier for students to study it back home. Problem solving besides being done individually is also done in groups of 4 people consisting of students who have different levels of academic ability and gender. Timing during group discussions by teachers is essential so that after discussion students have enough time to present the results of the discussion. Researchers always guide groups that have difficulty in solving problems given. If the difficulty is experienced by most groups, then the teacher provides classroom guidance in front of the class. After the discussion ends, some groups come to the front of the class to present the results of their discussion, while the other groups pay attention and respond when necessary. After the presentation the researcher asks some students to try to make a conclusion from the discussion, and the other students give additional or strengthening. If the conclusions made by the students are still lacking, researchers direct and give reinforcement to the correct conclusions. In order for students to better understand the material, the researcher provides additional training questions or homework to the students at the end of the lesson. Thus, learning achievement, student selfconfidence in learning, and implementation of learning can be optimal. Collaborative learning model applied in learning has been proven to improve student learning achievement and confidence. The statistical improvement of student achievement, student self-confidence and implementation of learning can be seen in the following table:
TABLE IV

IMPROVEMENT OF STUDENT'S LEARNING ACHIEVEMENT, STUDENT's SELF CONFIDENCE, AND LEARNING IMPLEMENTATION

\begin{tabular}{|c|c|c|c|c|}
\hline Variabel & \multicolumn{2}{|c|}{ Final Cycle 1} & \multicolumn{2}{|c|}{ Final Cycle 2} \\
\hline \multirow{6}{*}{ Student's Self Confidence } & \multicolumn{2}{|c|}{$6,25 \%$} & \multicolumn{2}{|c|}{$12,5 \%$} \\
\hline & \multicolumn{2}{|c|}{$78,125 \%$} & \multicolumn{2}{|c|}{$78,125 \%$} \\
\hline & \multicolumn{2}{|c|}{$9,375 \%$} & \multicolumn{2}{|c|}{$9,375 \%$} \\
\hline & \multicolumn{2}{|c|}{$6,25 \%$} & \multicolumn{2}{|c|}{$0 \%$} \\
\hline & \multicolumn{2}{|c|}{$0 \%$} & \multicolumn{2}{|c|}{$0 \%$} \\
\hline & \multicolumn{2}{|c|}{ 103,1563 (High) } & \multicolumn{2}{|c|}{ 109,2188 (High) } \\
\hline \multirow{2}{*}{ Knowledge/Skills } & \multicolumn{2}{|c|}{$59,375 \%$} & \multicolumn{2}{|c|}{$100 \%$} \\
\hline & \multicolumn{2}{|c|}{77,1875} & \multicolumn{2}{|c|}{87,9167} \\
\hline \multirow{3}{*}{ Learning process } & Teacher & Student & Teacher & Student \\
\hline & $92,61 \%$ & $91,67 \%$ & $100 \%$ & $100 \%$ \\
\hline & \multicolumn{2}{|c|}{$93 \%$} & \multicolumn{2}{|c|}{$100 \%$} \\
\hline
\end{tabular}

From the table shows that there is an average increase in student achievement from cycle I to cycle II that is 77.1875 to 87.9167 . Based on the observation of the researcher and the teacher of learning achievement improvement is caused because the material learned in cycle II is classified as easy to understand material for the students compared to the material in cycle I. In addition, in the discussion in cycle I, many students are shy to ask the researchers but not shy to ask teacher. From the observation of the results of cycle I evaluation, many students have difficulty in determining the definition of matrix, determining matrix elements, and determining the solution of problems related to equality and transpose matrix. This of course resulted in low evaluation results obtained by students. From the observation of the evaluation result of cycle II, many students have difficulty in determining the solution related to matrix multiplication operation. In addition, the number of students who got the value of $\geqslant 75$ in cycle II more than the first cycle ie from 19 students in the first cycle to 32 students in cycle II, consequently there is an increase percentage of mastery from $59.375 \%$ to $100 \%$. Student confidence in cycle II is higher than student self confidence in cycle I. Based on observation, students in cycle II no longer shy to ask the researchers and have started to adapt to the learning model used so that they are more actively ask for guidance to researchers. The data obtained 
from the questionnaire of cycle II shows that students are categorized in high category. To improve the learning achievement of each cycle, improvements are always oriented to the principles and characteristics of collaborative learning model, so that the application of collaborative learning model really shows its influence on students' learning achievement and confidence.

In addition to the improvements made effective, the scope of the material discussed in cycle II is easier to understand by students than in cycle I ie, about simple matrix operations. In addition, students have no difficulty in using simple matrix operations. At the end of cycle II all research variables have reached the desired target. This indicates that learning mathematics by applying collaborative learning model has been able to improve student's learning achievement and student's self confidence in teaching and learning process. Researchers also experience improved teaching performance by applying collaborative learning models.

\section{IV.CONCLUSION}

After applied the model of collaborative learning on the subject matrix in class X MIPA 4SMA Negeri 2 Ngaglik Yogyakarta Lesson Year $2015 / 2016$ in the form of classroom action research, obtained some conclusions that is (1) There is increasing student confidence through collaborative learning model. The increase can be seen from the average of initial conditions, the final conditions of cycle 1 , and the end condition of cycle 2 in a row that is equal to 96.46875 ; 103.1563; and 109.2188 with each criterion that is medium, high, and high. The increase at the end of cycle 2 has exceeded the desired target of 106 with high criteria and (2) Collaborative learning model can improve students' self-confidence. The stages in the model of collaborative learning that can improve student self-confidence is at the stage of share and create. Because at this stage students are required to express their opinions and create new concepts or knowledge of the discussions they have made.
The suggestions that can be submitted based on the results of this study include (1) In the learning process, students are expected to be active especially in understanding the concepts described by teachers that ultimately can improve students' self-confidence and (2) Expected to teachers to be able applying collaborative learning model as an alternative learning model in the classroom so that will add new experience for teachers in recognizing the variation of learning in an effort to improve student achievement and student confidence.

\section{REFERENCES}

Adams, D \& Hamm, M. (2010). Demystify Math, Science, and Technology Creativity, Innovation, and Problem Solving. USA: Rowman \& Littlefield Publisher, Inc.

Burns, A. (2010). sDoing Action Research in English Languange Teaching. New York: Routledge

Goodsell, A.S., Maher, M.R., Tinto, V., et al (1992). Collaborative Learning: A Sourcebook for Higher Education. Washington : NCTLA.

Goel, M. \& Aggarwal, P. (2012). A Comparative Study of Self confident of Single Child and Child with Sibling. International Journal of Research in Social Sciences, 3, 89-98.

Laal, M \& Laal, M. (2011). Collaborative Learning: What is it?. Procedia-Social and Behavioral Sciences, 31, 491 -495 .

Mendikbud. 2013. Permendikbud Nomor 64 Tahun 2013 Tentang Standar Isi Pendidikan Dasar dan Menengah.

Parachin, V.M. (2003). Developing dynamic selfconfidence. Super Vision, 64, 13-15

Srivastava, S. K. (2013). To Study the Effect of Academic Achievement on the Level of Self confident. $J$. Psychosoc. Res., Vol. 8, No. 1, 41-51

Wagman, D. (1997). Bulding self-confidence part II. ProQuest Research Library, 9, 217-219

Zuliana, Eka. (2008). Meningkatkan Kemampuan Komunikasi Matematika Peserta Didik Kelas VIII MTs N Kudus Melalui Model Cooperative Learning tipe Jigsaw berbantuan Kartu Masalah Materi Kubus dan Balok. Diambil pada tanggal 11 Januari 2016, dari eprints.umk.ac.id/ 